\title{
Prognostic value and clinicopathological characteristics of PD-L1 overexpression in non-Hodgkin lymphoma: a meta-analysis
}

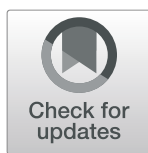

\author{
Qiang Zeng, Zhigang Liu and Ting Liu*
}

\begin{abstract}
Background: Programmed cell death ligand 1 (PD-L1) has already been detected in various carcinomas. In nonHodgkin lymphoma (NHL), however, the prognostic value of PD-L1 overexpression remains unclear.

Methods: A meta-analysis of $2321 \mathrm{NHL}$ patients from 12 studies was performed. Hazard ratios (HRs) with 95\% confidence intervals (Cls) were used to evaluate the correlation between PD-L1 overexpression and prognosis of $\mathrm{NHL}$, and odds ratios (ORs) with 95\% Cls were used to assess the association of PD-L1 overexpression with clinicopathological factors.

Results: The results showed that no significant difference between PD-L1 positive and negative groups was detected in NHL (HR: 1.40, 95\% Cl: 0.90-2.19; $P=0.137$ ). Nevertheless, the results indicated that PD-L1 overexpression was associated with poor prognosis in the subtype of diffuse large $B$ cell lymphoma (DLBCL) (HR: 1.70, 95\% Cl: $1.05-2.74 ; P=0.031$ ). We also performed subgroup analyses and meta-regression. The pooled OR showed that PD-L1 overexpression was associated with B symptoms, higher international prognostic index (IPI) score (3, 4, and 5 points) and Ann Arbor Stages III and IV.
\end{abstract}

Conclusions: The meta-analysis demonstrated that PD-L1 expression was not associated with prognosis of $\mathrm{NHL}$ but was associated with prognosis of DLBCL.

Keywords: PD-L1, Non-Hodgkin lymphoma, Prognosis, Meta-analysis

\section{Background}

Non-Hodgkin lymphoma (NHL), accounting for approximately $90 \%$ of lymphomas and comprising various subtypes, is a common hematological tumor. NHL is characterized by a series of malignant DNA repair obstacle events and activating proto-oncogene caused by viral or bacterial infection, immune dysfunction and genetic factors, resulting in a wide range of histological appearances and clinical features at presentation, including painless lymphadenopathy, B symptoms (weight loss $>10 \%$, night sweats, body temperature $>38^{\circ} \mathrm{C}$ ), and so on [1]. The prognoses of NHL patients remain poor, while the 5-year overall survival (OS) rates have improved [2, 3]. Therefore, we posit that there may be

\footnotetext{
*Correspondence: liuting@scu.edu.cn; liuting_57@126.com Department of Hematology, West China Hospital, Sichuan University, Chengdu 610041, China
}

other biomarkers potentially influencing the prognosis of NHL.

Programmed cell death ligand 1 (PD-L1), a $40 \mathrm{kDa}$ type 1 transmembrane protein, can activate $B, T$ cells, macrophages, and dendritic cells $[4,5]$. It was first found by Chen et al in 1999 [6]. It was reported that PD-L1 co-stimulated T-cell proliferation and interleukin-10 secretion, which was considered to be involved in the negative regulation of cell-mediated immune responses [6]. Under normal physiological conditions, immune checkpoints maintain self-tolerance and protect tissues from damage when the immune system is responding to pathogenic infections $[7,8]$. However, PD-L1, bound to programmed cell death 1 (PD-1), inhibits effector $\mathrm{T}$ cell function and activates immunosuppressive regulative $\mathrm{T}$ cell function, resulting in tumors escaping under pathological conditions [9-11]. which is a major mechanism of tumor recurrence and drug resistance [12]. Moreover, 
clinical research inferred that patients who had overexpression of PD-L1 in tumors had improved clinical outcomes after taking checkpoint blockades [13].

Cumulative studies showed that PD-L1 or PD-1 could be used to determine prognosis in various cancers, such as melanoma, non-small cell lung cancer, kidney cancer [5], and classic Hodgkin lymphoma [14]. Some studies have also assessed the prognostic value of PD-L1 overexpression in NHL. However, the results were quite different. Thus, we aim to identify the problem through performing a meta-analysis.

\section{Methods}

Our meta-analysis was conducted based on the Preferred Reporting Items for Systematic Reviews and MetaAnalyses (PRISMA) statement [15].

\section{Literature search}

Four databases-PubMed, Cochrane Library, Web of Science, and Embase-were used to retrieve articles that investigated the prognostic value of PD-L1 overexpression in NHL. Additionally, we used the following terms for searches: "PD-L1," "B7-H1," "CD274," "programmed cell death ligand 1," "lymphoma," "non-Hodgkin lymphoma," "NHL," "prognosis," and "survival." Articles published before January 2019 were included in the metaanalysis. We also performed a reference search.

\section{Selection of studies}

Two independent reviewers evaluated all potential articles. All candidate articles had to meet the following criteria: (1) patients' NHL diagnoses were histologically confirmed; (2) PD-L1 expression in lymphoid tissue was detected using immunohistochemistry (IHC); (3) hazard ratios (HRs) and 95\% confidence intervals (CIs) could be directly obtained from the studies or calculated using data from the articles; and (4) the studies were full-text and written in English. Moreover, any disputes were solved via discussion.

\section{Data extraction and quality assessment}

Two investigators independently extracted the data from articles. We extracted the following data: first author's name, study country, publication year, subtype, sample size, cut-off value of PD-L1, HRs and 95\% CIs for OS, PD-L1 positive number, follow-up period, treatment, Ann Arbor Stage and IHC antibodies. Furthermore, we contacted the author for original data if we were unable to calculate the effect size through the methods provided by Tierney [16]. We assessed these studies using the Newcastle-Ottawa Scale (NOS) [17], in which the score ranges from 0 to 9 points. We considered studies that received 6 points or above eligible for our meta-analysis. Any issues were resolved via discussion.

\section{Statistical analysis}

HRs with 95\% CIs were used to evaluate the correlation between PD-L1 overexpression and prognosis of NHL, and odds ratios (ORs) with 95\% CIs were used to assess the association of PD-L1 overexpression with clinicopathological factors. Heterogeneity tests were performed using the I-squared statistics, and an $\mathrm{I}^{2}>50 \%$ was considered significant. If heterogeneity was significant, we chose a random effect model to compute the pooled HR; otherwise, we selected a fixed effect model. Additionally, sensitivity analysis was used to assess the robustness of the pooled results, and publication bias was evaluated using Begg's test. Subgroup analyses and meta-regression were performed due to significant heterogeneity. All the analyses were performed by STATA 12.0 software (STATA, College, TX) and Revman 5.3 (Revman the Cochrane, Collaboration, Oxford, England).

\section{Results}

\section{Literature screening and characteristics}

The literature screening process is illustrated in Fig. 1. A total of 328 articles from the four databases and two articles from a manual reference search were initially selected. After removing duplicates, 224 studies remained. We excluded 189 articles after reviewing article abstracts. Next, seven articles were removed for failing to calculate the effect size; 14 studies were eliminated due to their being conference abstracts; and two studies were excluded because PD-L1 was not detected through IHC. Finally, altogether 12 articles encompassing 2321 patients were selected for the meta-analysis.

All characteristics of the studies are displayed in Table 1. Four studies were performed in China [18-21], four in Korea [22-25], two in Japan [26, 27], and one each was in the US [28] and Norway [29], respectively. The cut-off value was determined using the form of percentage except Cho's, which ranged from 2 to $50 \%$. According to the cut-off values, every article described the number of patients with PD-L1 overexpression. All studies referred to each disease stage according to Ann Arbor Staging except Bi's. In addition, all studies were retrospective and reported the association between PDL1 and OS. Patients in the studies had a histologically confirmed NHL diagnosis and subtype.

\section{Association between PD-L1 overexpression and OS in NHL}

We calculated a pooled HR of 1.40 (95\% CI: 0.90-2.19; $P=0.137$ ) for OS. The result indicated that PD-L1 overexpression was not associated with NHL prognosis. Significant heterogeneity, however, existed among the selected studies $\left(\mathrm{I}^{2}=70.6 \%, P<0.001\right.$; Fig. 2$)$. 


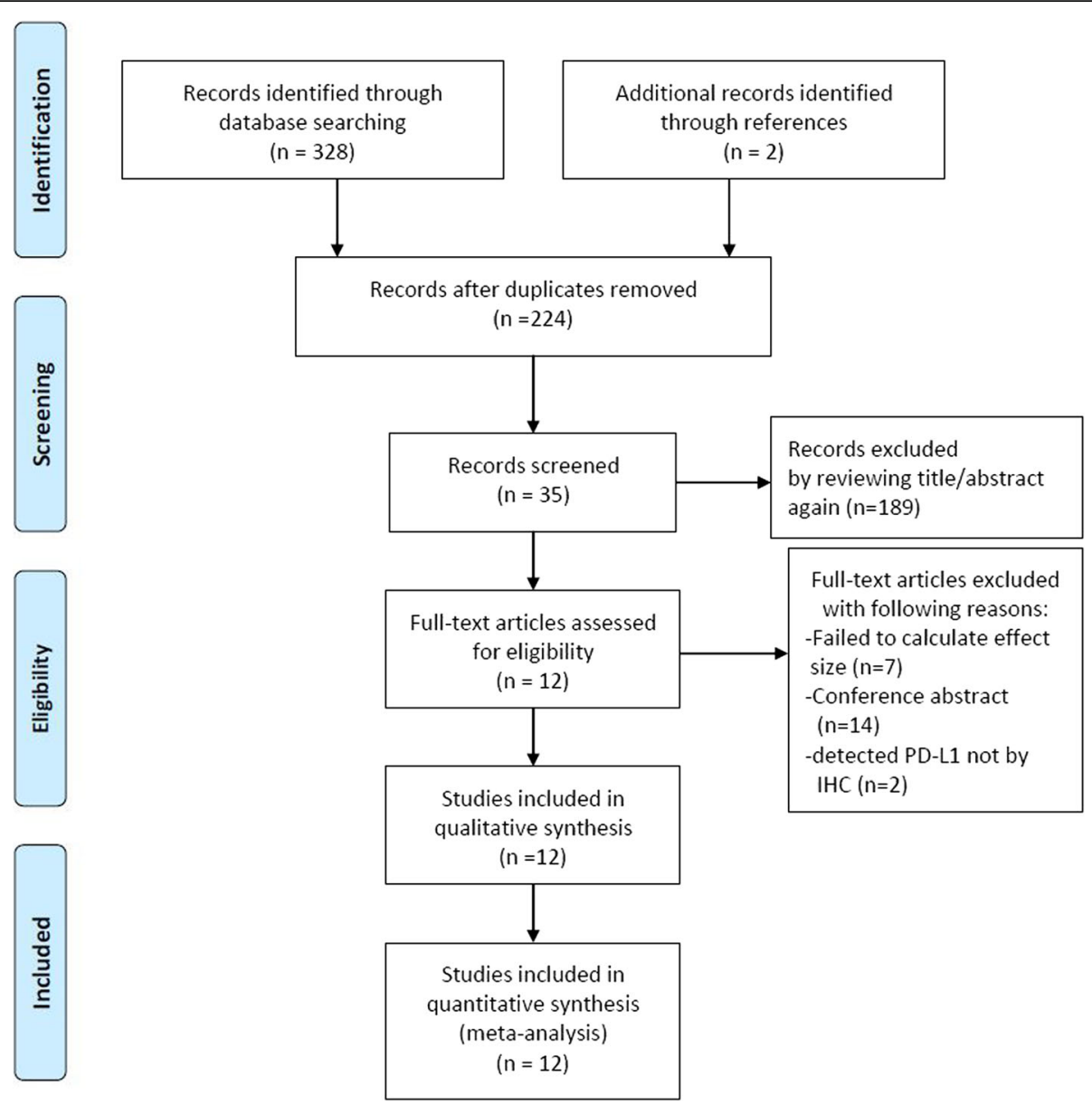

Fig. 1 Flow chart of the included articles

Association of PD-L1 overexpression with OS in DLBCL DLBCL, accounting for $30-40 \%$ of NHL, is the most common subtype of NHL. There were 863 DLBCL patients from six articles in our study. A metaanalysis was performed that was designed to assess prognosis among DLBCL patients. The result showed that the pooled HR was 1.70 (95\% CI: $1.05-2.74 ; P=$ 0.031 ) with $\mathrm{I}^{2}=47.2 \%$ (Fig. 3). This indicated that PD-L1 overexpression potentially predicted a poor prognosis in DLBCL patients.

\section{Association between PD-L1 overexpression and clinicopathological characteristics}

We also investigated the association of PD-L1 overexpression with clinicopathological characteristics. The results suggested that PD-L1 overexpression was more frequent in patients with $B$ symptoms $(\mathrm{OR}=1.91,95 \%$ CI: $1.17-3.10 ; P=0.09)$, stage III and IV (OR $=1.49,95 \%$ CI: $1.09-2.04 ; P=0.01)$ and international prognostic index (IPI) score of 3 to 5 points $(\mathrm{OR}=1.79,95 \% \mathrm{CI}$ :
1.26-2.56; $P=0.001$ ). However, there was no significant difference in the subgroups of gender and age (Fig. 4).

\section{Subgroup and sensitivity analysis}

Subgroup analyses were conducted by tumor type, country, sample size, cut-off value, therapy, antibody source, and type. Subgroup analysis by country showed HR of 2.86 (95\% CI: $1.44-5.66 ; P=0.003)$ in China, $1.99(95 \%$ CI: $1.29-3.08 ; P=0.002)$ in Japan, and 0.47 (95\% CI: $0.29-0.77 ; P=0.002)$ in Korea. In addition, when cut-off value $\geq 30 \%$, HR was 2.54 (95\% CI: $1.56-4.12 ; P<0.001$ ) with $\mathrm{I}^{2}=37 \%$ (Table 2 ). Sensitivity analyses demonstrated that our pooled results were robust even when omitting anyone of the included studies by turn in NHL and DLBCL (Figs. 5 and 6).

\section{Meta-regression analysis}

Furthermore, meta-regression was performed for the source of heterogeneity in NHL. The results showed that sample size $(P=0.638)$, treatment $(P=0.229)$, location 


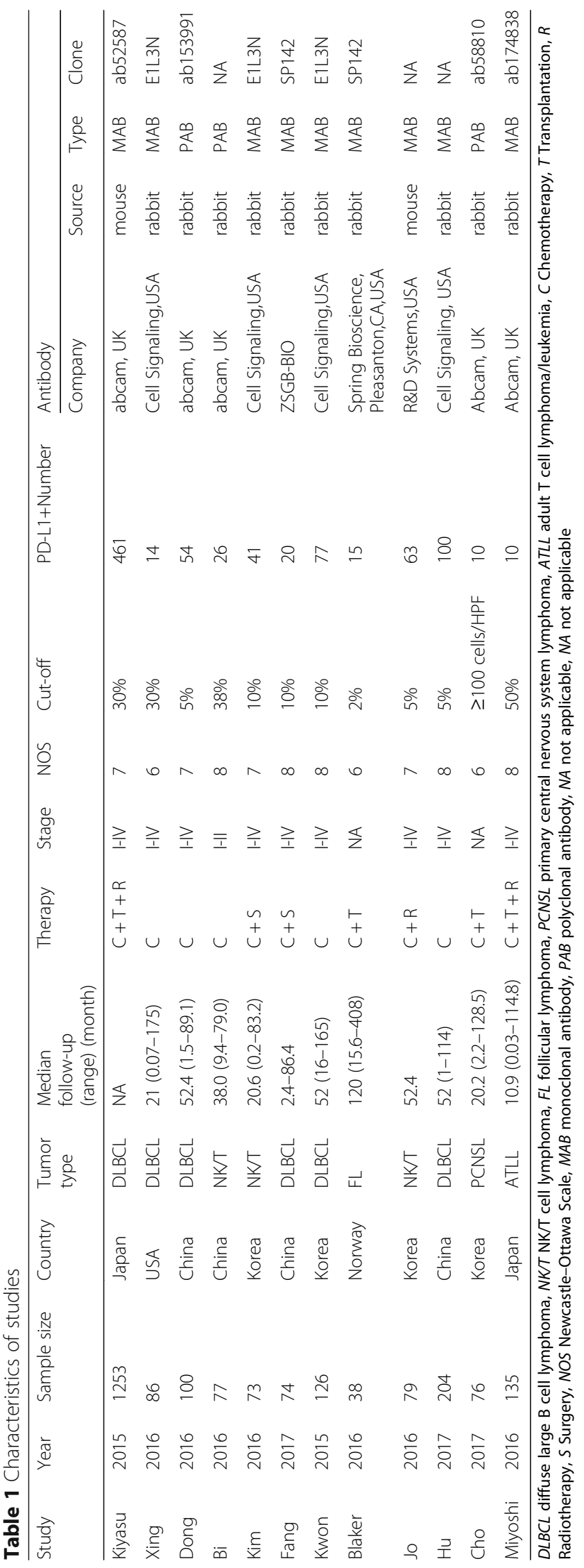




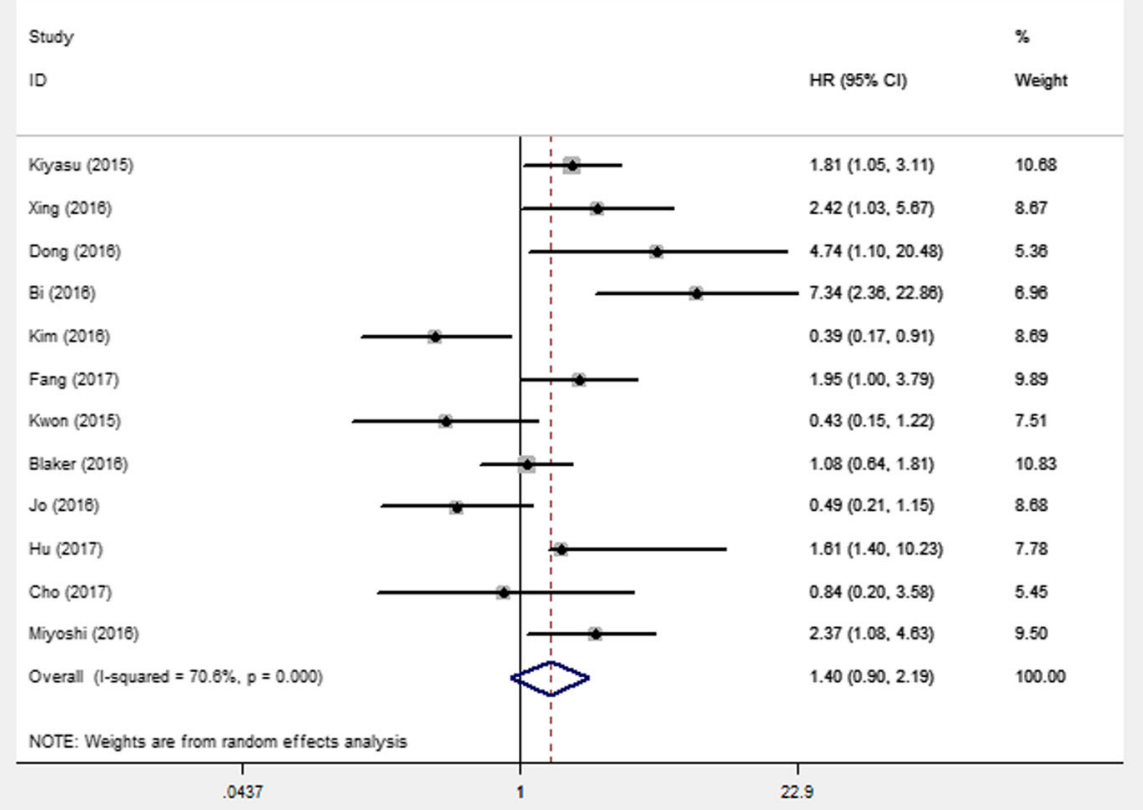

Fig. 2 Forest plots of studies evaluating hazard ratio (HR) with 95\% Cl of PD-L1 for overall survival (OS) in NHL

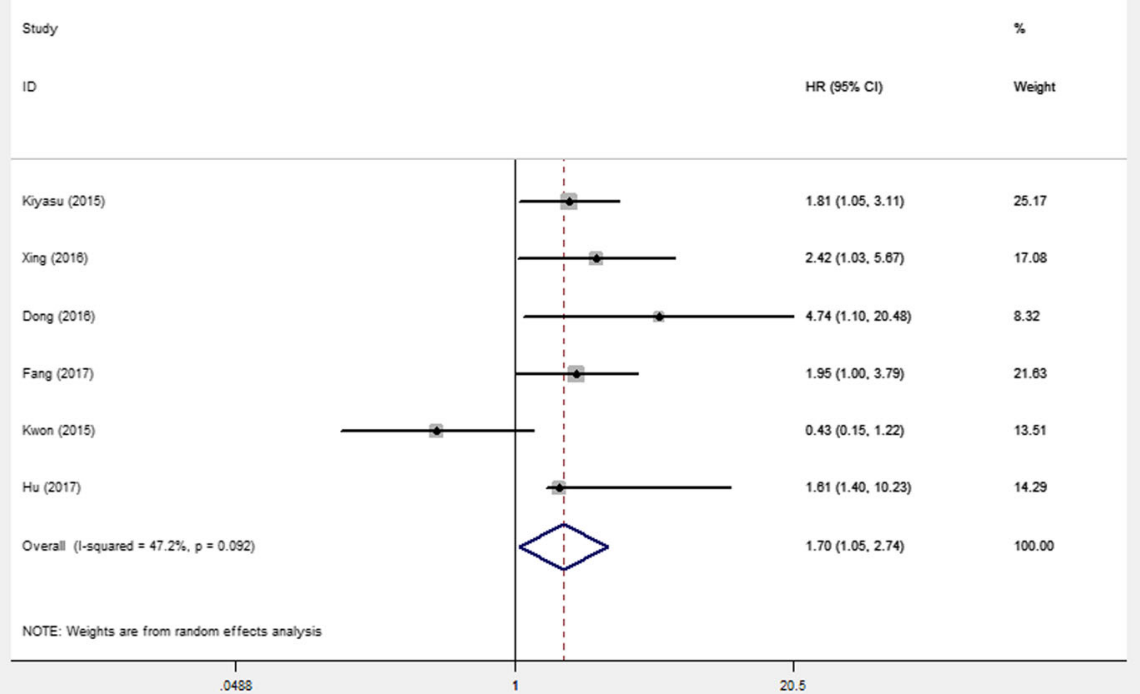

Fig. 3 Forest plots of studies evaluating hazard ratio (HR) with 95\% Cl of PD-L1 for overall survival (OS) in DLBCL 
A

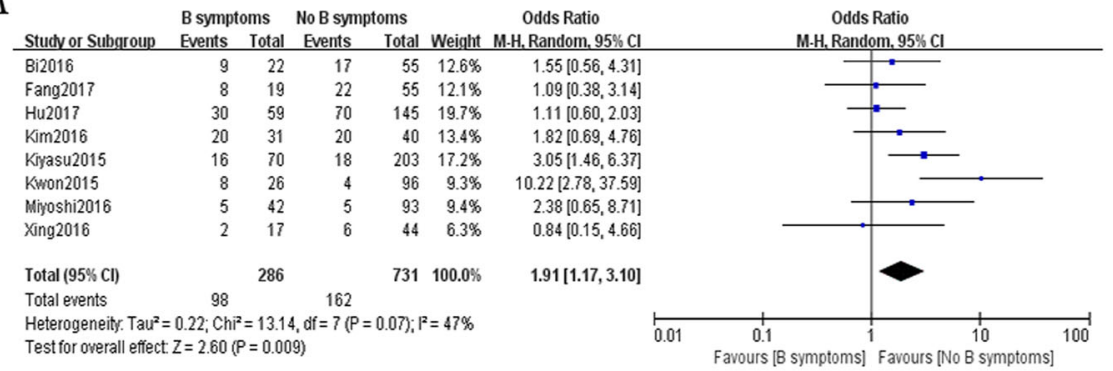

B

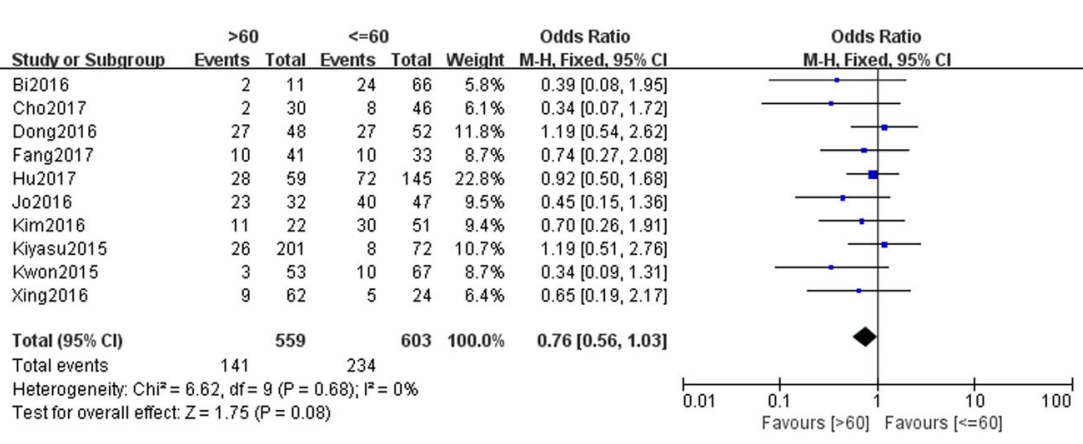

C

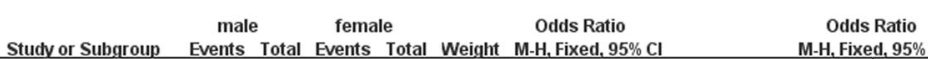
Events Total Events Total Weight M-H, Fixed, 95\% Cl Cho2017

Dong2016

Fang201?

Kiyasu2015 Miyoshi2016 Xing2016

$\begin{array}{rrrrrr}16 & 42 & 10 & 35 & 9.1 \% & 1.54[0.59,4.03] \\ 4 & 39 & 6 & 37 & 7.4 \% & 0.59[0.15,2.29] \\ 35 & 60 & 19 & 40 & 12.7 \% & 1.55[0.69,3.46]\end{array}$

$\begin{array}{rrrrrr}35 & 60 & 19 & 40 & 12.7 \% & 1.55[0.69,3.46] \\ 13 & 41 & 7 & 33 & 7.1 \% & 1.72[0.60,4.99]\end{array}$

$\begin{array}{rrrrrr}13 & 41 & 7 & 33 & 7.1 \% & 1.72[0.60,4.99] \\ 52 & 115 & 48 & 89 & 39.7 \% & 0.71[0.40,1.23]\end{array}$

$\begin{array}{rrrrr}52 & 115 & 48 & 89 & 39.7 \%\end{array}$

$\begin{array}{llllll}23 & 140 & 11 & 133 & 12.6 \% & 2.18[1.02,4.67\end{array}$

Total $(95 \% \mathrm{Cl})$

Total events

553

$472 \quad 100.0 \% \quad 1.22[0.90,1.66]$

Heterogeneity: $\mathrm{Chi}^{2}=8.43, \mathrm{df}=7(\mathrm{P}=0.30) ; \mathrm{l}^{2}=17 \%$

Test for overall effect: $Z=1.28(\mathrm{P}=0.20)$

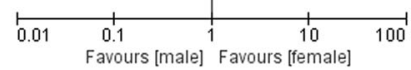

D
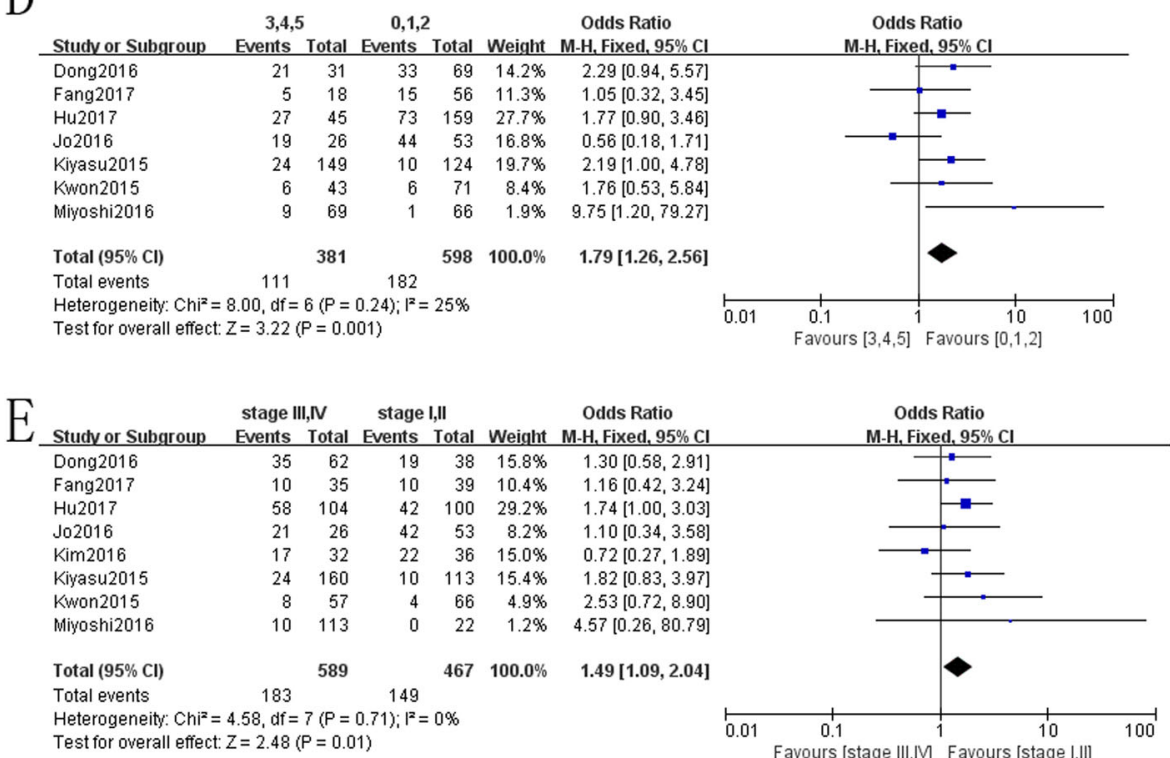

Fig. 4 Forest plots for the association of PD-L1 overexpression with clinicopathological factors. a B symptoms; b age; c gender; $\mathbf{d}$ IPI score; e Ann Arbor stage 
Table 2 Subgroup analysis for OS

\begin{tabular}{|c|c|c|c|c|c|}
\hline Subgroup & Number of studies & Number of patients & $\mathrm{HR}(95 \% \mathrm{Cl})$ & $P$ value & Heterogeneity \\
\hline \multicolumn{6}{|l|}{ Location } \\
\hline China & 4 & 455 & $2.86(1.44-5.66)$ & 0.003 & $P^{2}=45.1 \% ; P=0.141$ \\
\hline Korea & 4 & 354 & $0.47(0.29-0.77)$ & 0.002 & $I^{2}=0 \% ; P=0.836$ \\
\hline USA & 1 & 86 & $2.42(1.03-5.67)$ & 0.042 & / \\
\hline Norway & 1 & 38 & $1.08(0.64-1.81)$ & 0.771 & / \\
\hline Japan & 2 & 1388 & $1.99(1.29-3.08)$ & 0.002 & $I^{2}=0 \% ; P=0.557$ \\
\hline \multicolumn{6}{|l|}{ Cut-off value } \\
\hline$\geq 30 \%$ & 4 & 1627 & $2.54(1.56-4.12)$ & $<0.001$ & $I^{2}=37 \% ; P=0.19$ \\
\hline$\leq 10 \%$ & 7 & 694 & $0.98(0.55-1.73)$ & 0.938 & $I^{2}=68.7 \% ; P=0.004$ \\
\hline \multicolumn{6}{|l|}{ Tumor type } \\
\hline DLBCL & 6 & 1842 & $1.70(1.05-2.74)$ & 0.031 & $I^{2}=47.2 \% ; P=0.092$ \\
\hline NKTT & 3 & 229 & $1.07(0.21-5.59)$ & 0.935 & $I^{2}=89.3 \% ; P<0.001$ \\
\hline $\mathrm{FL}$ & 1 & 38 & $1.08(0.64-1.81)$ & 0.771 & / \\
\hline PCNSL & 1 & 76 & $0.84(0.20-3.55)$ & 0.813 & / \\
\hline ATLL & 1 & 136 & 2.37 (1.15-4.90) & 0.020 & / \\
\hline \multicolumn{6}{|l|}{ Therapy } \\
\hline Chemotherapy & 5 & 1573 & $2.16(0.85-5.49)$ & 0.105 & $I^{2}=73.6 \% ; P=0.004$ \\
\hline Chemotherapy+other treatments & 7 & 748 & $1.12(0.69-1.84)$ & 0.646 & $I^{2}=68.5 \% ; P=0.004$ \\
\hline \multicolumn{6}{|l|}{ Sample size } \\
\hline$\geq 100$ & 5 & 1818 & $1.64(0.90-3.01)$ & 0.529 & $P^{2}=57.8 \% ; P=0.05$ \\
\hline$<100$ & 7 & 503 & $1.26(0.66-2.43)$ & 0.480 & $I^{2}=76.8 \% ; P<0.001$ \\
\hline \multicolumn{6}{|l|}{ Antibody type } \\
\hline MAB & 9 & 2068 & $1.17(0.75-1.83)$ & 0.476 & $I^{2}=68.4 \% ; P=0.001$ \\
\hline PAB & 3 & 253 & $3.23(0.89-11.74)$ & 0.075 & $I^{2}=64 \% ; P=0.062$ \\
\hline \multicolumn{6}{|l|}{ Antibody source } \\
\hline Rabbit & 10 & 989 & $1.52(0.91-2.55)$ & 0.212 & $I^{2}=70.6 \% ; P<0.001$ \\
\hline Mouse & 2 & 1332 & $0.98(0.27-3.52)$ & 0.978 & $P^{2}=84.5 \% ; P=0.011$ \\
\hline
\end{tabular}

$H R$ hazard ratio, $C l$ confidence interval, $D L B C L$ diffuse large B cell lymphoma, NK/T NK/T cell lymphoma, $F L$ follicular lymphoma, $P C N S L$ primary central nervous system lymphoma, ATLL adult T cell lymphoma/leukemia, MAB monoclonal antibody, PAB polyclonal antibody

$(P=0.107)$, tumor type $(P=0.916)$, and cut-off value $(P=0.058)$ did not contribute to the heterogeneity.

\section{Publication bias}

Begg's test was used to assess the publication bias, which revealed no publication bias for either NHL $(P=0.880)$ nor DLBCL $(P=0.920)$.

\section{Discussion}

This is a meta-analysis designed to investigate the relationship between PD-L1 overexpression and the prognosis of NHL. The association of PD-L1 overexpression with some clinicopathological factors was also evaluated. The pooled HR of 1.40 (95\% CI: $0.90-2.19 ; P=0.137$ ) was calculated for 2321 patients from 12 studies, potentially indicating no significant correlation between PDL1 and NHL prognosis. Nevertheless, the result suggested that PD-L1 overexpression was associated with poor prognosis in DLBCL patients. Figure 4 illustrates that patients with B symptoms, IPI scores of 3 to 5 points, and Ann Arbor Stage III or IV possessed overexpression of PD-L1.

Subgroup analysis and meta-regression showed no contribution to the heterogeneity in NHL. However, perhaps some problems contributed to the heterogeneity. Although IHC was used to detect PD-L1 protein in tumor cells in all studies, different studies adopted different procedures [30], antibody clones and thresholds [31]. Vranic et al. [32] suggested that anti-PD-L1 clones SP142 and SP263 exhibit an excellent concordance. Additionally, other confounding factors influence the expression of PD-L1. Studies [33, 34] indicated that anaplastic lymphoma kinase (ALK) up-regulates PD-L1 expression. Research also suggested that STAT3 regulates PD-L1 expression, and it was demonstrated that the inhibitor of STAT3 abrogated the expression of PD- 


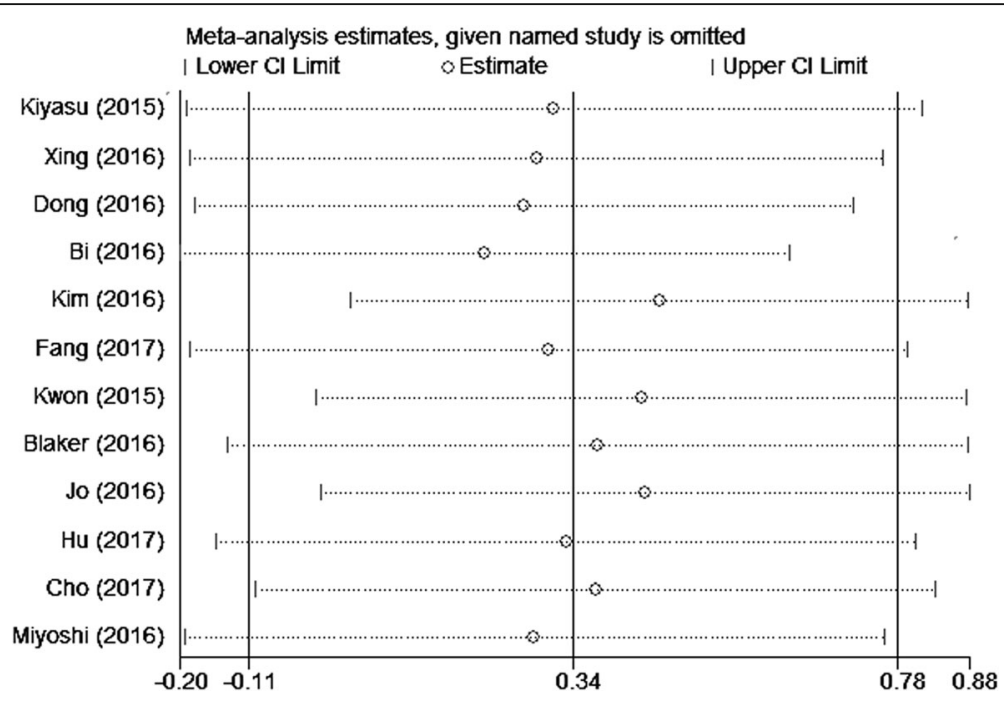

Fig. 5 Sensitivity analysis on the correlation between PD-L1 and OS in NHL

L1 $[35,36]$. It was also shown that tumor cells that overexpress PD-L1 protein have been frequently detected in EBV-positive lymphomas [20, 26, 37, 38].

The response to treatment is also not associated with the level of PD-L1 expression. Currently, PD-1 blockades are mostly employed clinically. Some clinical trials $[39,40]$ showed that patients with B-cell NHL indeed responded well to PD-1 blockades combined with rituximab. Zinzani et al. [41] found that PD-1 blockades used alone also benefited B-cell NHL patients. Two studies [42, 43] showed that PD-1 blockades helped relapsed or refractory NHL patients increase complete response rate. However, the level of PD-L1 expression in patients was quite different, and PDL1was not even detected in some patients. These findings indicate that the level of PD-L1 expression is not associated with the prognosis of NHL patients.

Nevertheless, recent studies have uncovered the concrete functional mechanism of PD-L1 in DLBCL. PD-L1, bound to PD-1, caused phosphorylation of AKT, which urge $\mathrm{m}$-TOR to activate its downstream molecules, such as P43-BP1 and P-P70S6K, finally resulting in proliferation and progression of malignant cells $[19,44,45]$. Theoretically, this explains why overexpression of PD-L1 causes short OS in DLBCL patients. Unfortunately, in other NHL subtypes, there is currently no such theory.

To the best of our knowledge, Zhao et al. [46] performed the first meta-analysis, which included 9 studies, to explore the relationship between PD-L1 overexpression and prognosis in NHL patients and concluded that

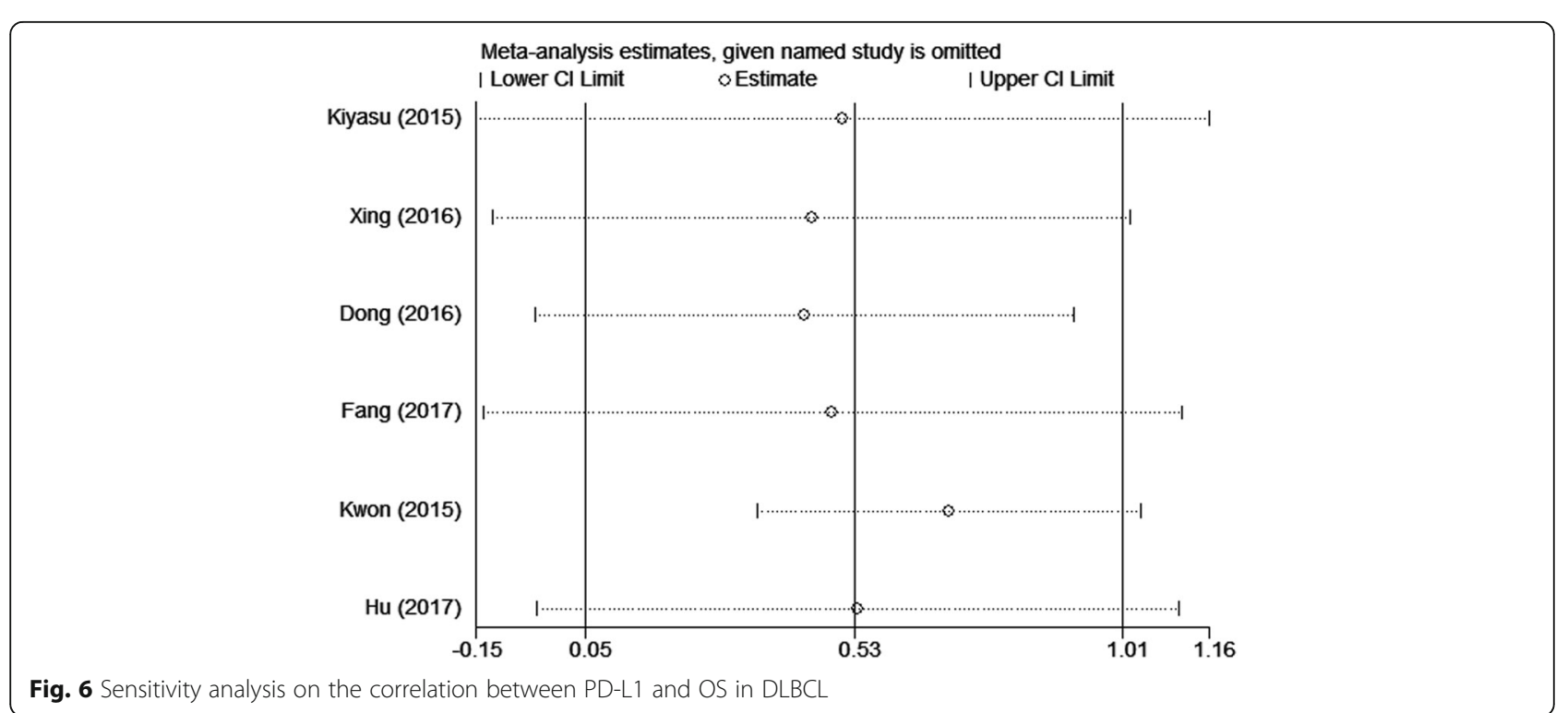


PD-L1 overexpression has an association with poor prognosis in NHL and DLBCL but not with natural killer/T-cell (NK/T) lymphoma. We brought 12 studies with a total of 2321 patients into our meta-analysis and obtained conclusions that are different from Zhao et al.'s. In DLBCL and NK/T lymphoma (data not show), we reached the same conclusion as did Zhao et al. Yet, our conclusion regarding the overall result of NHL differs from that of Zhao et al's due to our having included three more studies than they did. We also adopted two tools to conduct meta-analysis and did sub-analysis.

Several limitations, however, must be considered in interpreting our findings. First, the total sample size of the included studies was small. Second, other clinicopathological factors-such as EBV infection, tumor size, and central neutral system invasion-were not included in the analysis due to insufficient materials. Third, although we performed subgroup analysis by cut-off value, we did not know the best cut-off value for stratification of NHL patients in clinical management.

\section{Conclusions}

In conclusion, our pooled results showed that overexpression of PD-L1 was not associated with OS in NHL patients; rather, it was associated with the subtype of DLBCL, indicating that PD-L1 could perhaps predict the prognosis of DLBCL. Furthermore, PD-L1 overexpression was associated with the clinicopathological factors of B symptoms, IPI score, and Ann Arbor Stage. Nevertheless, studies on other specific NHL subtypes using standardized immunological tests are needed to further explore the relationship between PD-L1 overexpression and prognosis of NHL.

\section{Abbreviations}

Cl: Confidence interval; DLBCL: Diffuse large B cell lymphoma; HR: Hazard ratio; IHC: Immunohistochemistry; IPI: International prognostic index; NHL: Non-Hodgkin lymphoma; NOS: Newcastle-Ottawa Scale; OR: Odds ratio; PD-1: Programmed cell death 1; PD-L1: Programmed cell death ligand 1; PRISMA: Preferred Reporting Items for Systematic Reviews and Meta-Analyses

\section{Acknowledgments}

Not applicable.

\section{Authors' contributions}

The study was conceived, designed, and performed by QZ. QZ analyzed the data, and ZL contributed to the materials and tools. QZ wrote this paper. ZL retrieved all the text articles. All the work was performed under TL's instruction. All authors have read and approved the manuscript, and ensure that this is the case.

\section{Funding}

This work was not financed by any grants.

\section{Availability of data and materials} Not applicable.

\section{Ethics approval and consent to participate}

This study did not obtain samples or data of human participants or animals. All the data involved were obtained from published articles. Informed consent was obtained from all included participants in the study.
Consent for publication

Not applicable.

\section{Competing interests}

The authors declare that they have no competing interests.

Received: 3 October 2019 Accepted: 16 January 2020

Published online: 28 January 2020

\section{References}

1. Shankland KR, Armitage JO, Hancock BW. Non-Hodgkin lymphoma. Lancet. 2012;380(9844):848-57

2. Kubuschok B, Held G, Pfreundschuh M. Management of diffuse large B-cell lymphoma (DLBCL). Cancer Treat Res. 2015;165:271-88.

3. Al-Hamadani M, Habermann TM, Cerhan JR, Macon WR, Maurer MJ, Go RS. Non-Hodgkin lymphoma subtype distribution, geodemographic patterns, and survival in the US: A longitudinal analysis of the National Cancer Data Base from 1998 to 2011. Am J Hematol. 2015;90(9):790-5.

4. Ohaegbulam KC, Assal A, Lazar-Molnar E, Yao Y, Zang X. Human cancer immunotherapy with antibodies to the PD-1 and PD-L1 pathway. Trends Mol Med. 2015;21(1):24-33.

5. Li Y, Li F, Jiang F, Lv X, Zhang R, Lu A, Zhang G. A Mini-Review for Cancer Immunotherapy: Molecular Understanding of PD-1/PD-L1 Pathway \&amp; Translational Blockade of Immune Checkpoints. Int J Mol Sci. 2016;17(7):1151

6. Dong H, Zhu G, Tamada K, Chen L. B7-H1, a third member of the B7 family, co-stimulates T-cell proliferation and interleukin-10 secretion. Nat Med. 1999:5(12):1365-9.

7. Pardoll DM. The blockade of immune checkpoints in cancer immunotherapy. Nat Rev Cancer. 2012;12(4):252-64.

8. Chakravarti N, Prieto VG. Predictive factors of activity of anti-programmed death-1/programmed death ligand-1 drugs: immunohistochemistry analysis. Transl Lung Cancer Res. 2015;4(6):743-51.

9. Francisco LM, Sage PT, Sharpe AH. The PD-1 pathway in tolerance and autoimmunity. Immunol Rev. 2010;236:219-42.

10. Francisco LM, Salinas VH, Brown KE, Vanguri VK, Freeman GJ, Kuchroo VK, Sharpe AH. PD-L1 regulates the development, maintenance, and function of induced regulatory T cells. J Exp Med. 2009;206(13):3015-29.

11. Haxhinasto $S$, Mathis $D$, Benoist C. The AKT-mTOR axis regulates de novo differentiation of CD4+Foxp3+ cells. J Exp Med. 2008;205(3):565-74.

12. Finn OJ. Immuno-oncology: understanding the function and dysfunction of the immune system in cancer. Ann Oncol. 2012;23(Suppl 8):viii6-9.

13. Patel SP, Kurzrock R. PD-L1 expression as a predictive biomarker in Cancer immunotherapy. Mol Cancer Ther. 2015;14(4):847-56.

14. Pembrolizumab Approved for Hodgkin Lymphoma. Cancer Discovery. 2017;7(5):Of1.

15. Moher D, Liberati A, Tetzlaff J, Altman DG. Preferred reporting items for systematic reviews and meta-analyses: the PRISMA statement. PLoS Med. 2009;6(7):e1000097.

16. Tierney JF, Stewart LA, Ghersi D, Burdett S, Sydes MR. Practical methods for incorporating summary time-to-event data into meta-analysis. Trials. 2007;8:16.

17. Stang A. Critical evaluation of the Newcastle-Ottawa scale for the assessment of the quality of nonrandomized studies in meta-analyses. Eur J Epidemiol. 2010;25(9):603-5.

18. Fang X, Xiu B, Yang Z, Qiu W, Zhang L, Zhang S, Wu Y, Zhu X, Chen X, Xie $S$, et al. The expression and clinical relevance of PD-1, PD-L1, and TP63 in patients with diffuse large B-cell lymphoma. Medicine. 2017;96(15):e6398.

19. Dong L, Lv H, Li W, Song Z, Li L, Zhou S, Qiu L, Qian Z, Liu X, Feng L, et al. Co-expression of PD-L1 and P-AKT is associated with poor prognosis in diffuse large B-cell lymphoma via PD-1/PD-L1 axis activating intracellular AKT/mTOR pathway in tumor cells. Oncotarget. 2016;7(22):33350-62.

20. Bi XW, Wang H, Zhang WW, Wang JH, Liu WJ, Xia ZJ, Huang HQ, Jiang WQ, Zhang YJ, Wang L. PD-L1 is upregulated by EBV-driven LMP1 through NFkappaB pathway and correlates with poor prognosis in natural killer/T-cell lymphoma. J Hematol Oncol. 2016;9(1):109.

21. Hu LY, Xu XL, Rao HL, Chen J, Lai RC, Huang HQ, Jiang WQ, Lin TY, Xia ZJ, Cai QQ. Expression and clinical value of programmed cell death-ligand 1 (PD-L1) in diffuse large B cell lymphoma: a retrospective study. Chin J Cancer. 2017;36(1):94.

22. Kwon D, Kim S, Kim PJ, Go H, Nam SJ, Paik JH, Kim YA, Kim TM, Heo DS, Kim CW, et al. Clinicopathological analysis of programmed cell death 1 and 
programmed cell death ligand 1 expression in the tumour microenvironments of diffuse large B cell lymphomas. Histopathology. 2016; 68(7):1079-89.

23. Kim WY, Jung HY, Nam SJ, Kim TM, Heo DS, Kim CW, Jeon YK. Expression of programmed cell death ligand 1 (PD-L1) in advanced stage EBV-associated extranodal NKT cell lymphoma is associated with better prognosis. Virchows Archiv. 2016;469(5):581-90.

24. Jo JC, Kim M, Choi Y, Kim HJ, Kim JE, Chae SW, Kim H, Cha HJ. Expression of programmed cell death 1 and programmed cell death ligand 1 in extranodal NK/T-cell lymphoma, nasal type. Ann Hematol. 2017;96(1):25-31.

25. Cho H, Kim SH, Kim SJ, Chang JH, Yang WI, Suh CO, Kim YR, Jang JE, Cheong JW, Min YH, et al. Programmed cell death 1 expression is associated with inferior survival in patients with primary central nervous system lymphoma. Oncotarget. 2017;8(50):87317-28.

26. Kiyasu J, Miyoshi H, Hirata A, Arakawa F, Ichikawa A, Niino D, Sugita Y, Yufu $Y$, Choi I, Abe $Y$, et al. Expression of programmed cell death ligand 1 is associated with poor overall survival in patients with diffuse large B-cell lymphoma. Blood. 2015;126(19):2193-201.

27. Miyoshi H, Kiyasu J, Kato T, Yoshida N, Shimono J, Yokoyama S, Taniguchi H, Sasaki Y, Kurita D, Kawamoto K, et al. PD-L1 expression on neoplastic or stromal cells is respectively a poor or good prognostic factor for adult T-cell leukemia/lymphoma. Blood. 2016;128(10):1374-81.

28. Xing W, Dresser K, Zhang R, Evens AM, Yu H, Woda BA, Chen BJ. PD-L expression in EBV-negative diffuse large B-cell lymphoma: clinicopathologic features and prognostic implications. Oncotarget. 2016;7(37):59976-86.

29. Blaker YN, Spetalen S, Brodtkorb M, Lingjaerde OC, Beiske K, Ostenstad B, Sander B, Wahlin BE, Melen CM, Myklebust JH, et al. The tumour microenvironment influences survival and time to transformation in follicular lymphoma in the rituximab era. Br J Haematol. 2016;175(1):102-14.

30. Herbst RS, Soria JC, Kowanetz M, Fine GD, Hamid O, Gordon MS, Sosman JA, McDermott DF, Powderly JD, Gettinger SN, et al. Predictive correlates of response to the anti-PD-L1 antibody MPDL3280A in cancer patients. Nature. 2014;515(7528):563-7.

31. Scognamiglio G, De Chiara A, Di Bonito M, Tatangelo F, Losito NS, Anniciello A, De Cecio R, D'Alterio C, Scala S, Cantile M, et al. Variability in Immunohistochemical Detection of Programmed Death Ligand 1 (PD-L1) in Cancer Tissue Types. Int J Mol Sci. 2016;17(5):790.

32. Vranic S, Ghosh N, Kimbrough J, Bilalovic N, Bender R, Arguello D, Veloso Y, Dizdarevic A, Gatalica Z. PD-L1 status in refractory lymphomas. PLoS One. 2016;11(11):e0166266.

33. Roussel H, De Guillebon E, Biard L, Mandavit M, Gibault L, Fabre E, Antoine M, Hofman P, Beau-Faller M, Blons $H$, et al. Composite biomarkers defined by multiparametric immunofluorescence analysis identify ALK-positive adenocarcinoma as a potential target for immunotherapy. Oncoimmunology. 2017;6(4):e1286437.

34. Cha YJ, Shim HS. PD-L1 expression and CD8+ tumor-infiltrating lymphocytes are associated with ALK rearrangement and clinicopathological features in inflammatory myofibroblastic tumors. Oncotarget. 2017;8(52):89465-74.

35. Atsaves V, Tsesmetzis N, Chioureas D, Kis L, Leventaki V, Drakos E, Panaretakis T, Grander D, Medeiros L, Young KH, et al. PD-L1 is commonly expressed and transcriptionally regulated by STAT3 and MYC in ALKnegative anaplastic large-cell lymphoma. Leukemia. 2017;31(7):1633-7.

36. Ma C, Horlad H, Pan C, Yano H, Ohnishi K, Fujiwara Y, Matsuoka M, Lee A, Niidome T, Yamanaka R, et al. Stat3 inhibitor abrogates the expression of PD-1 ligands on lymphoma cell lines. J Clin Exp Hematop. 2017;57(1):21-5.

37. Chen BJ, Chapuy B, Ouyang J, Sun HH, Roemer MG, Xu ML, Yu H, Fletcher CD, Freeman GJ, Shipp MA, et al. PD-L1 expression is characteristic of a subset of aggressive B-cell lymphomas and virus-associated malignancies. Clin Cancer Res. 2013;19(13):3462-73.

38. Laurent C, Fabiani B, Do C, Tchernonog E, Cartron G, Gravelle P, Amara N, Malot S, Palisoc MM, Copie-Bergman C, et al. Immune-checkpoint expression in Epstein-Barr virus positive and negative plasmablastic lymphoma: a clinical and pathological study in 82 patients. Haematologica. 2016;101(8):976-84.

39. Berger R, Rotem-Yehudar R, Slama G, Landes S, Kneller A, Leiba M, KorenMichowitz M, Shimoni A, Nagler A. Phase I safety and pharmacokinetic study of CT-011, a humanized antibody interacting with PD-1, in patients with advanced hematologic malignancies. Clin Cancer Res. 2008;14(10): 3044-51.
40. Westin JR, Chu F, Zhang M, Fayad LE, Kwak LW, Fowler N, Romaguera J, Hagemeister F, Fanale M, Samaniego F, et al. Safety and activity of PD1 blockade by pidilizumab in combination with rituximab in patients with relapsed follicular lymphoma: a single group, open-label, phase 2 trial. Lancet Oncol. 2014;15(1):69-77.

41. Zinzani PL, Ribrag V, Moskowitz CH, Michot JM, Kuruvilla J, Balakumaran A, Zhang Y, Chlosta S, Shipp MA, Armand P. Safety and tolerability of pembrolizumab in patients with relapsed/refractory primary mediastinal large B-cell lymphoma. Blood. 2017;130(3):267-70.

42. Lesokhin AM, Ansell SM, Armand P, Scott EC, Halwani A, Gutierrez M, Millenson MM, Cohen AD, Schuster SJ, Lebovic D, et al. Nivolumab in patients with relapsed or refractory hematologic malignancy: preliminary results of a phase lb study. J Clin Oncol. 2016;34(23):2698-704.

43. Kwong YL, Chan TSY, Tan D, Kim SJ, Poon LM, Mow B, Khong PL, Loong F, Au-Yeung R, lqbal J, et al. PD1 blockade with pembrolizumab is highly effective in relapsed or refractory NK/T-cell lymphoma failing I-asparaginase. Blood. 2017;129(17):2437-42.

44. Uddin S, Hussain AR, Siraj AK, Manogaran PS, Al-Jomah NA, Moorji A, Atizado V, Al-Dayel F, Belgaumi A, El-Solh H, et al. Role of phosphatidylinositol 3'-kinase/AKT pathway in diffuse large B-cell lymphoma survival. Blood. 2006;108(13):4178-86.

45. Xu ZZ, Xia ZG, Wang AH, Wang WF, Liu ZY, Chen LY, Li JM. Activation of the $\mathrm{PI3K} / \mathrm{AKT} / \mathrm{mTOR}$ pathway in diffuse large B cell lymphoma: clinical significance and inhibitory effect of rituximab. Ann Hematol. 2013;92(10): 1351-8.

46. Zhao $S$, Zhang $M$, Zhang $Y$, Meng $H$, Wang $Y$, Liu $Y$, Jing J, Huang L, Sun $M$, Zhang $Y$, et al. The prognostic value of programmed cell death ligand 1 expression in non-Hodgkin lymphoma: a meta-analysis. Cancer Biol Med. 2018;15(3):290-8.

\section{Publisher's Note}

Springer Nature remains neutral with regard to jurisdictional claims in published maps and institutional affiliations.

\section{Ready to submit your research? Choose BMC and benefit from:}

- fast, convenient online submission

- thorough peer review by experienced researchers in your field

- rapid publication on acceptance

- support for research data, including large and complex data types

- gold Open Access which fosters wider collaboration and increased citations

- maximum visibility for your research: over $100 \mathrm{M}$ website views per year

At BMC, research is always in progress.

Learn more biomedcentral.com/submissions 